\title{
PARAMETRIC STUDY ON PROGRESSIVE COLLAPSE FOR UNSYMMETRICAL R C STRUCTURE
}

\author{
Abhisheka B R \\ M. Tech in Structural Engineering from Gogte Institute of Technology, \\ Belagavi, Karnataka, India \\ Kanchan B Kanagali \\ Assistant professor, Gogte Institute of Technology, \\ Belagavi, Karnataka, India
}

\begin{abstract}
The term progressive collapse is defined as the spread of an initial local failure in a manner analogous to a chain reaction that leads to partial or total collapse of a building structure. The characteristic of progressive collapse is that the final state of failure is disproportionately greater than the failure that initiated the collapse. In this study, progressive collapse analysis is carried out on a Y shaped 12 storey building of RC framed structure. Then the building is assessed using linear static analysis by removing column at different locations. The columns are removed at ground floor in different locations each one at a time and analysis is carried out using ETABS 2016 and then the Demand Capacity Ratio (DCR) value is evaluated. Finally it can be concluded that $\mathrm{Y}$-shape building is safe against progressive collapse when center column and corner column is removed compare to other cases and provision of $\mathrm{RC}$ bracings at which column collapse around the column is best economical solution to prevent the progressive collapse.
\end{abstract}

Keywords: Progressive Collapse Analysis, DCR Value, GSA Guidelines, Linear Static Analysis, Etabs 2016, Bracings,

\section{INTRODUCTION}

The first collapse in 1968 in residential building of Ranon Point happened because of gas break out in the outer side and it attracted the notice of all and later on similarly happened in Skyline Tower building, L'Ambiance and Bankeer Trust Building. The GSA guidelines in June 2003 and United Facilities Criteria (UFC) in the year of 2005 and 2009 in the field of progressive collapse were published. When progressive collapse occurs the building will collapse fully or partially, this is due to the failure of any one of the building components like column, beam and slabs due to abnormal loads or extra loads. In most of the cases column failure is the main reason for the progressive collapse, the column failure results in the failure of beams connecting it, then the failure of beams leads to failure of surrounding or adjacent building components and finally building collapses.

\section{A. Objectives}

1) To understand the performance of irregular or unsymmetrical RC structure under progressive collapse.

2) To understand and identify the behavior of unsymmetrical structure and the action or sequences of failure of plan for column removal at different locations.

3) To evaluate the DCR of the structure against progressive collapse at different location of column removal.

4) To calculate the Demand Capacity Ratio (DCR) and evaluate the results as per the acceptance criteria provided in U.S. General Service Administration (GSA) guidelines.

5) To calculate the DCR by introducing bracings at ground floor to reduce the effect of progressive collapse.

\section{GENERAL SERVICE ADMINISTRATION GUIDELINES}

According to guidelines of GSA, the failure occurs in the structural member at first in the structure refers the local failure, this local failure leads to global failure i.e. collapse of whole structure. Various methods used for progressive collapse analysis are linear static analysis, non-linear static analysis, linear dynamic analysis and non-linear dynamic analysis. The GSA guidelines suggests different locations to remove 2 or more columns for analysis,

A. Column at exterior side in longer direction. 
B. Column at exterior side in shorter direction.

C. Columns located in the corner.

D. Columns located at interior of the building.

1) Linear Static Methods: The loading is taken as per General Service Administration (GSA) guidelines and design is done using IS 456-2000 Load combinations as per GSA guidelines

i) Before column removal: [DL + 0.25LL]

ii) After column removal: $2 *[\mathrm{DL}+0.25 \mathrm{LL}]$

Where, D L- Self weight or dead load and L LLive load

Analysis will be carried out by using Etabs-2016.

2) Demand Capacity Ratio (DCR) Value: As per GSA guidelines, the DCR is defined as the ratio of load acting on the member and load withstand by the member. Based on the DCR value of the member obtained from the analysis, the structural components are considered as the safe and sound. Otherwise the structural member is said to be damaged due to DCR exceed the limit and leads to collapse of structure, if member is safe when DCR value is within the limit.

DCR = load acting on the member / load withstand by the member

$$
=\mathrm{L}_{\text {acting }} / \mathrm{L}_{\text {capacity }}
$$

$\mathrm{L}_{\text {acting }}=$ Load or stress on the element. BM, SF and $\mathrm{AF}$ of beams and columns are considered.

$\mathrm{L}_{\text {capacity }}=$ Load or stress withstand by the element in terms of BM, SF, AF

As per GSA guidelines, the limiting acceptable value of DCR is limited,

i) For symmetrical structure 2 and

ii) For unsymmetrical structures 1.5

3) Method of applying the progressive collapse load on the structure

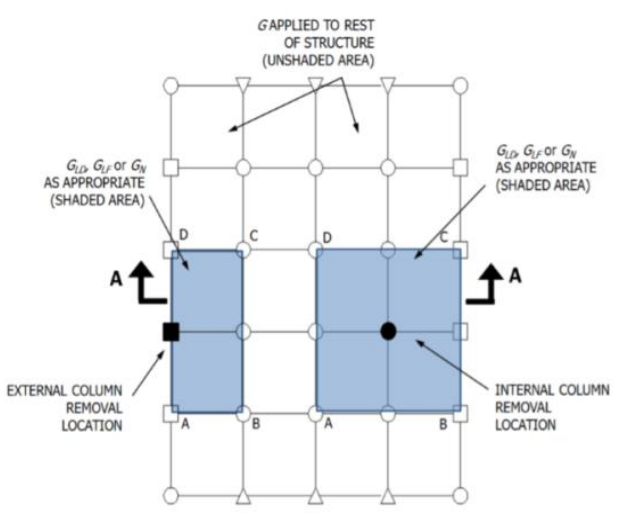

PLAN VIEW

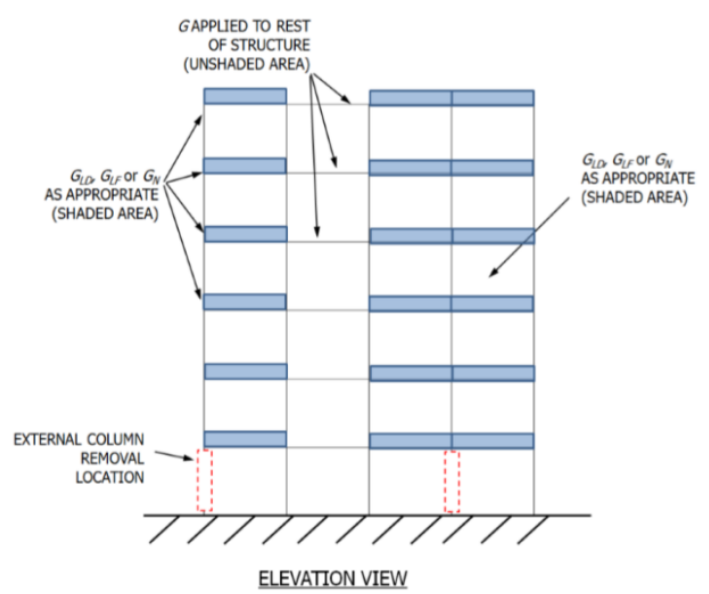

Fig. 1: Loads and Load Locations for External and Internal Column Removal for Linear Static Models (Left Side Demonstrates External Column Removal; Right Side Shows Internal Column Removal)

\section{METHODOLOGY}

For the analysis, a 12 storied Y-shape R C structure having storey height of $3 \mathrm{~m}$ each and consists of 12 storeys with bay size as 5 meters in both the direction.

The building details are as follows,

Table 1: Material properties and gravity loads on structure

\begin{tabular}{|c|c|c|}
\hline \multicolumn{3}{|c|}{ Materials } \\
\hline Concrete & & $\mathrm{f}_{\mathrm{ck}} 30$ \\
\hline $\begin{array}{c}\text { Steel } \\
\text { Reinforcement }\end{array}$ & & $\mathrm{F}_{\mathrm{e}} 500$ \\
\hline \multicolumn{3}{|c|}{ Dimensions } \\
\hline Slab & & $150 \mathrm{~mm}$ \\
\hline Wall & & $300 \mathrm{~mm}$ \\
\hline Beam & \multicolumn{2}{|c|}{$300 \mathrm{~mm}$ X 500mm } \\
\hline Bracing & \multicolumn{2}{|c|}{$300 \times 300 \mathrm{~mm}$} \\
\hline \multirow{3}{*}{ Column } & $\begin{array}{l}1-4 \\
\text { storey }\end{array}$ & $300 \mathrm{~mm} * 800 \mathrm{~mm}$ \\
\hline & $\begin{array}{c}5-8 \\
\text { storey }\end{array}$ & $300 \mathrm{~mm} * 600 \mathrm{~mm}$ \\
\hline & $\begin{array}{l}9-12 \\
\text { storey }\end{array}$ & $300 \mathrm{~mm} * 450 \mathrm{~mm}$ \\
\hline \multicolumn{3}{|c|}{ Loads } \\
\hline Live Load & & $3 \mathrm{kN} / \mathrm{m}^{2}$ \\
\hline Floor load & & $1.5 \mathrm{kN} / \mathrm{m}^{2}$ \\
\hline Wall load & & $13.75 \mathrm{kN} / \mathrm{m}$ \\
\hline
\end{tabular}


International Journal of Engineering Applied Sciences and Technology, 2020

Vol. 5, Issue 1, ISSN No. 2455-2143, Pages 543-549

Published Online May 2020 in IJEAST (http://www.ijeast.com)

\begin{tabular}{|l|c|}
\hline \multicolumn{1}{|c|}{ Parapet load } & $3.7 \mathrm{kN} / \mathrm{m}$ \\
\hline $\begin{array}{l}\text { Collapse load for } \\
\text { floor area above } \\
\text { removed column }\end{array}$ & $26.4 \mathrm{kN} / \mathrm{m}^{2}$ \\
\hline $\begin{array}{l}\text { Collapse load for } \\
\text { floor area away } \\
\text { from removed } \\
\text { Column }\end{array}$ & $6 \mathrm{kN} / \mathrm{m}^{2}$ \\
\hline
\end{tabular}

The analysis is done using linear static method for the following cases.

1) Shorter side middle exterior column removal at ground floor.

2) Middle interior column removal at ground floor.

3) Corner column removed at ground floor.

4) Column removed at center in ground floor.

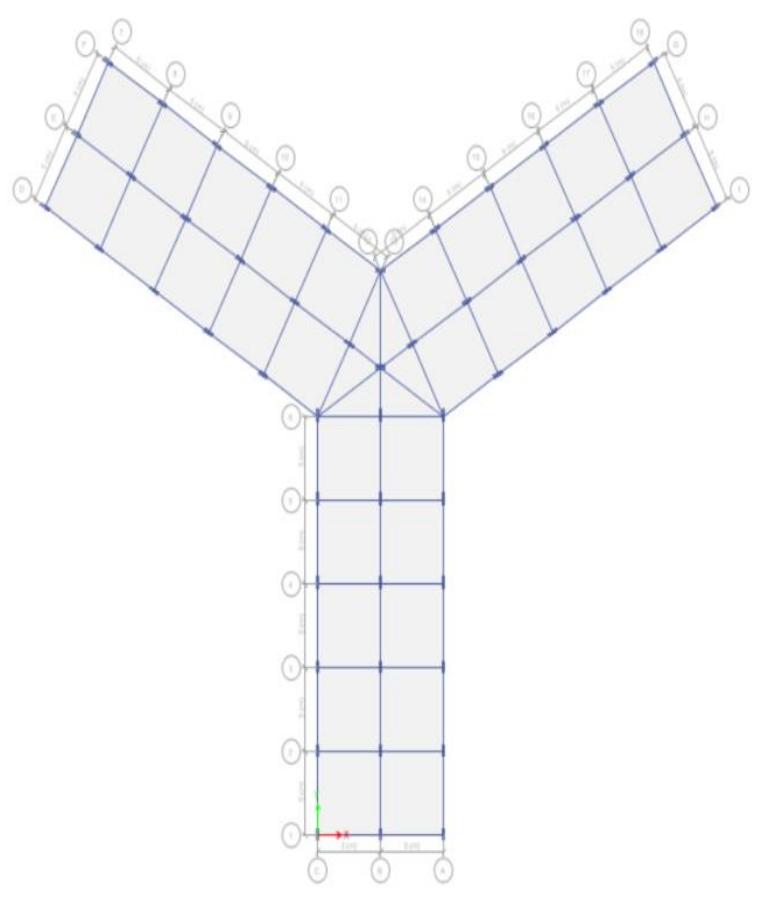

a) Plan

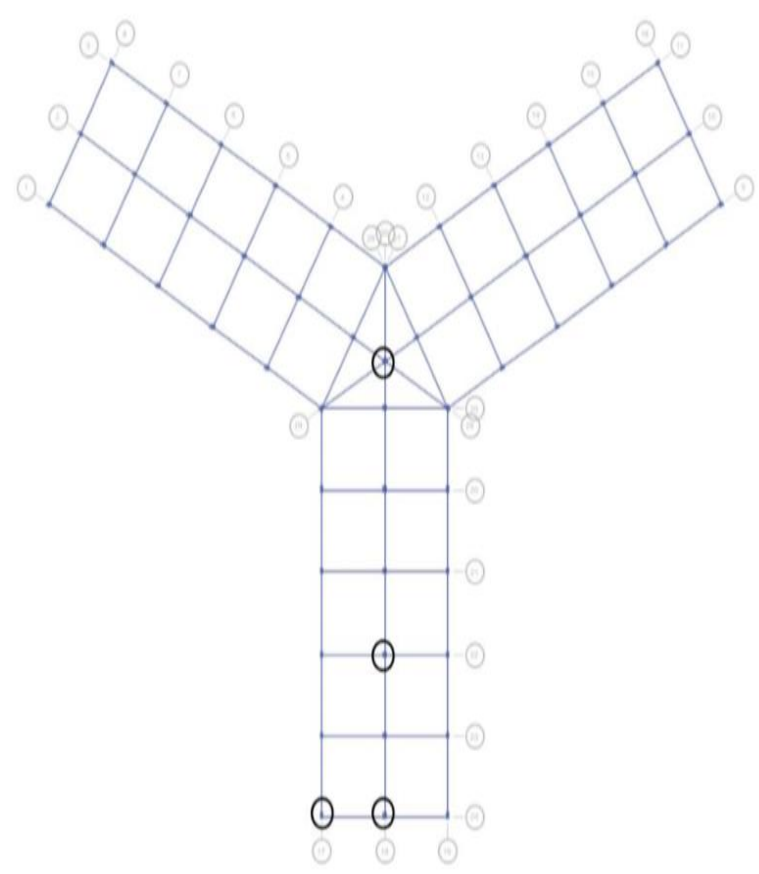

b) Column Removing Locations

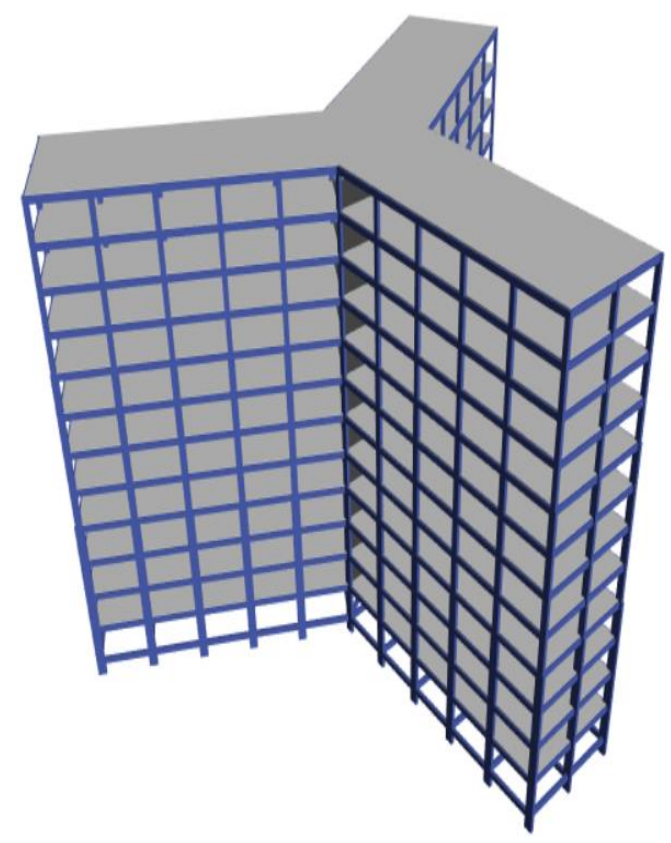

c) Without Bracing 


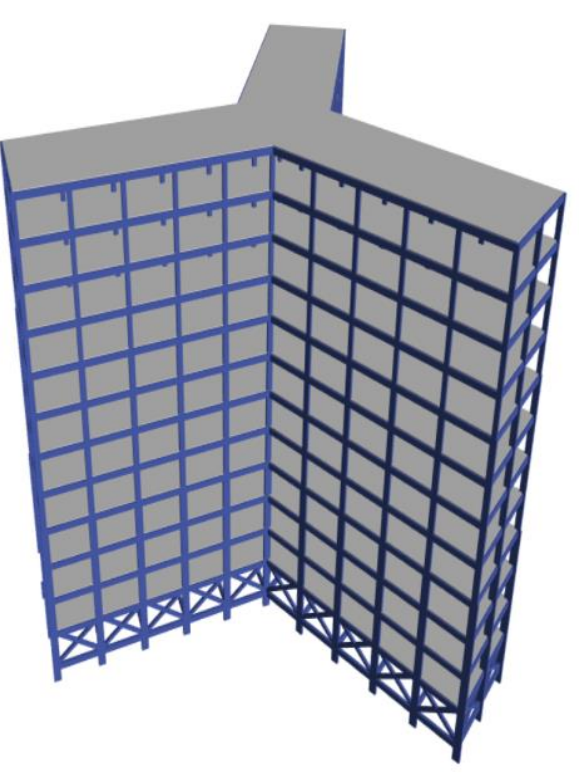

d) With Exterior Bracing

Fig. 2: Y-shape model details and isometric view

\section{RESULTS AND DISCUSSION}

1) Corner column removed at ground floor

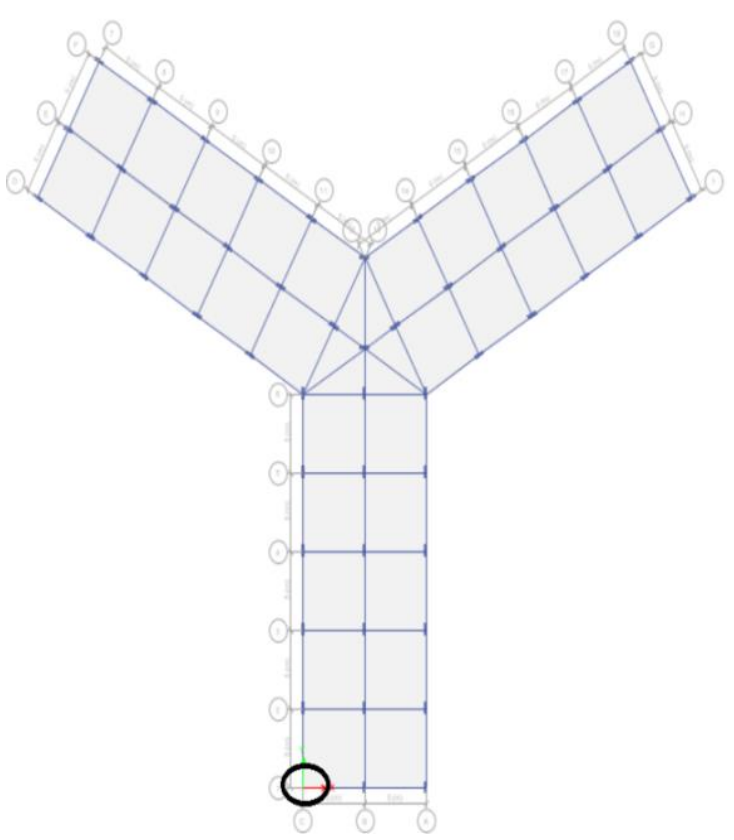

Fig. 3: Corner column removal location in plan

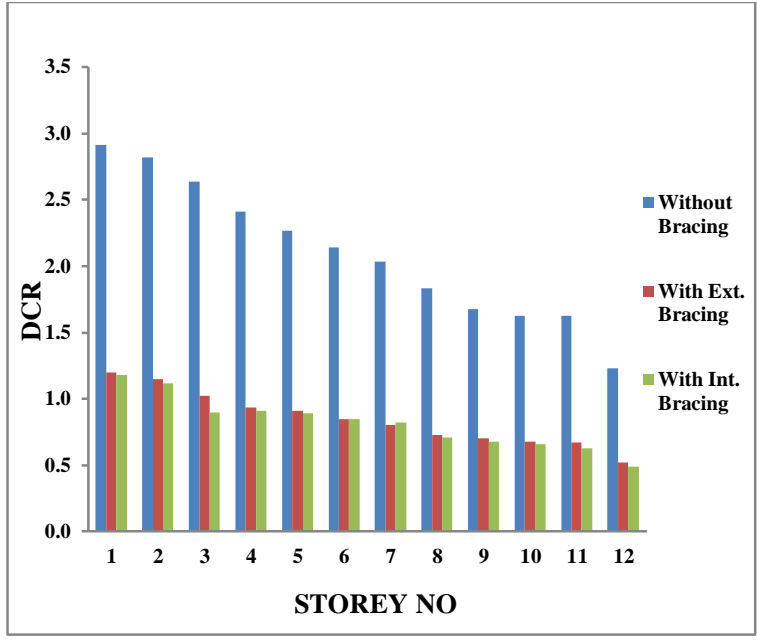

Graph 1: DCR vs Storeys for corner column removal

In this case, the DCR value of the beam upto $11^{\text {th }}$ storey will exceeds the 1.5 and the providing the exterior and interior bracings at ground floor, the DCR value of all storeys within 1.5. Hence progressive collapse is arrested, when bracings are provided.

2) Shorter side middle exterior column removal at ground floor

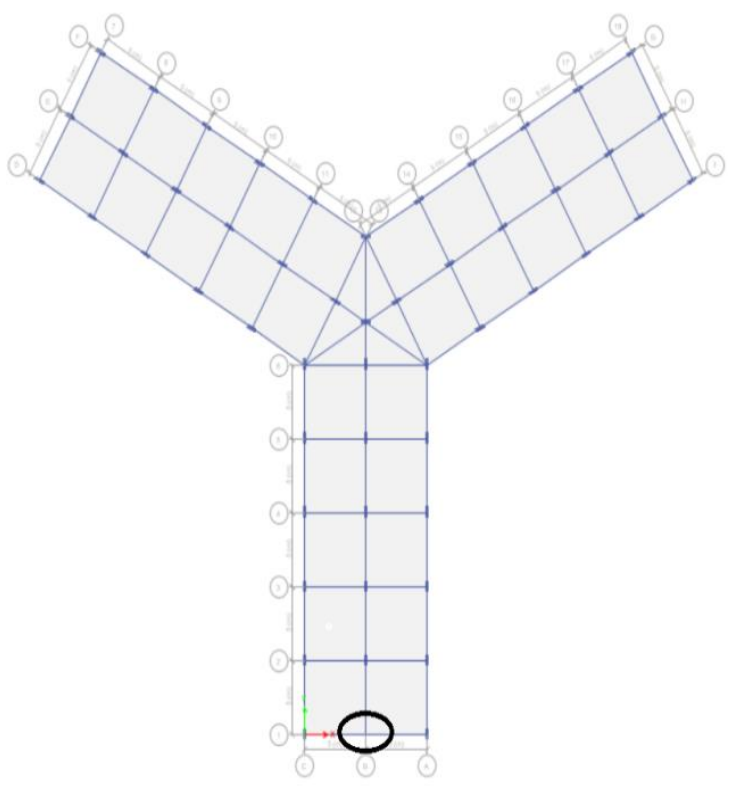

Fig. 4: Shorter side middle exterior column removal location in plan 


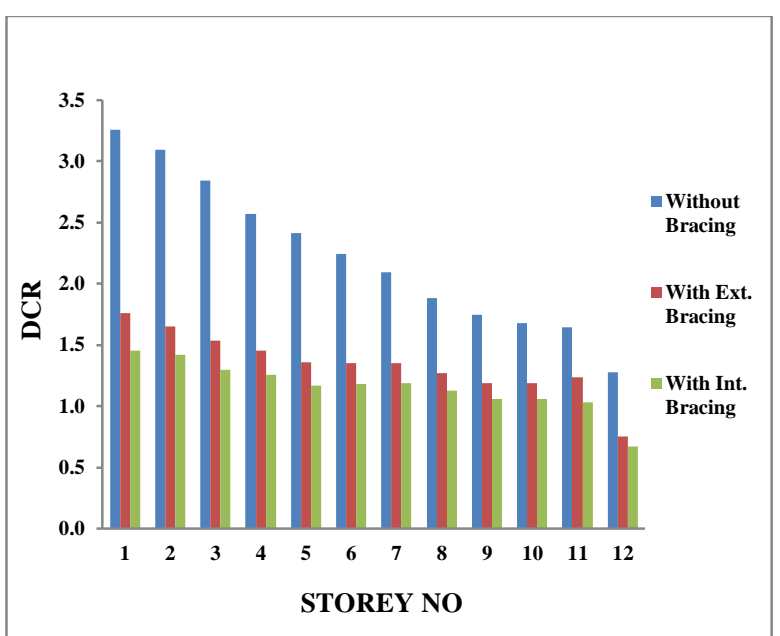

Graph 2: DCR vs Storeys for Shorter side middle exterior column removal

In this case, the DCR value of the beam upto $11^{\text {th }}$ storey will exceed 1.5 and by providing the exterior bracings at ground floor, the DCR value will exceeds the 1.5 upto $3^{\text {rd }}$ storey. On providing the interior bracings at ground floor, the DCR value will be within 1.5 . Hence in this case progressive collapse is prevented by providing the interior bracings.

3) Middle interior column removal at ground floor

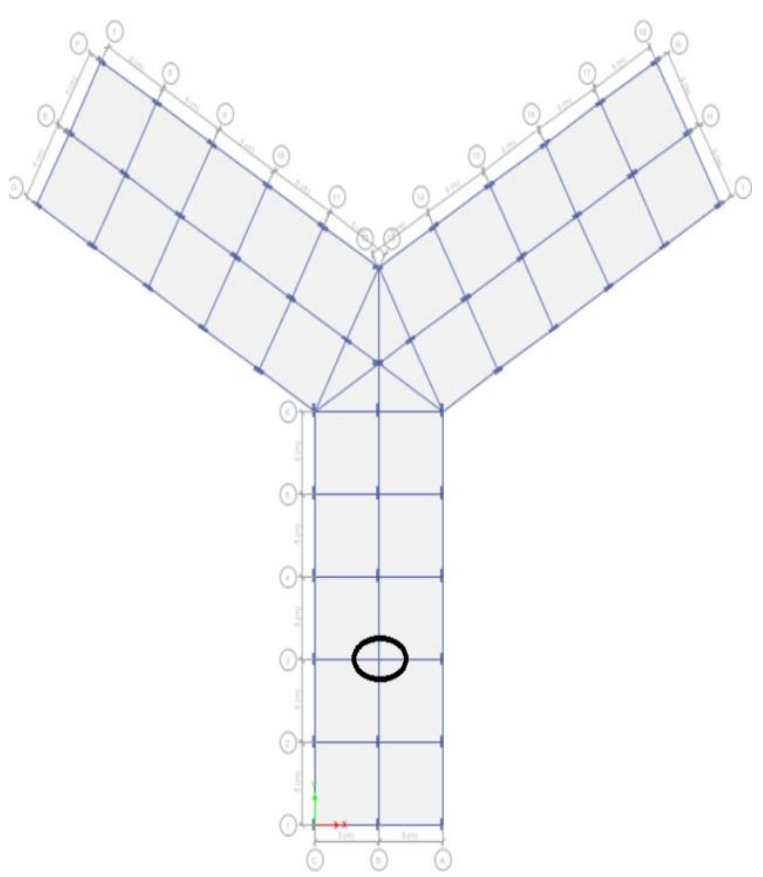

Fig. 5: Middle interior column removal location in plan

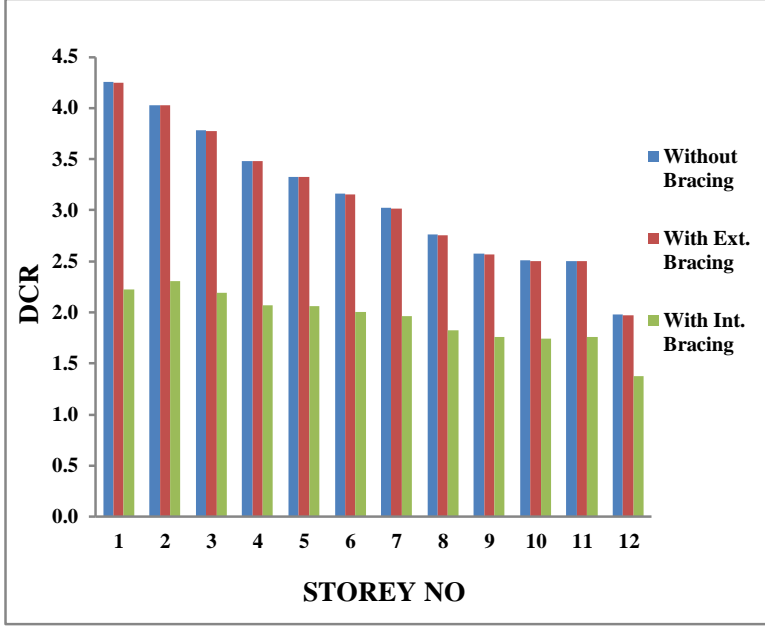

Graph 3: DCR vs Storeys for Middle interior column removal

In this case, the DCR value of the beam will exceed 1.5 for both without bracing and with exterior bracing. On providing the interior bracings also the DCR value upto $11^{\text {th }}$ storey will exceeds 1.5 . Hence progressive collapse occurs and it is more critical compared to other cases.

4) Column removed at center in ground floor

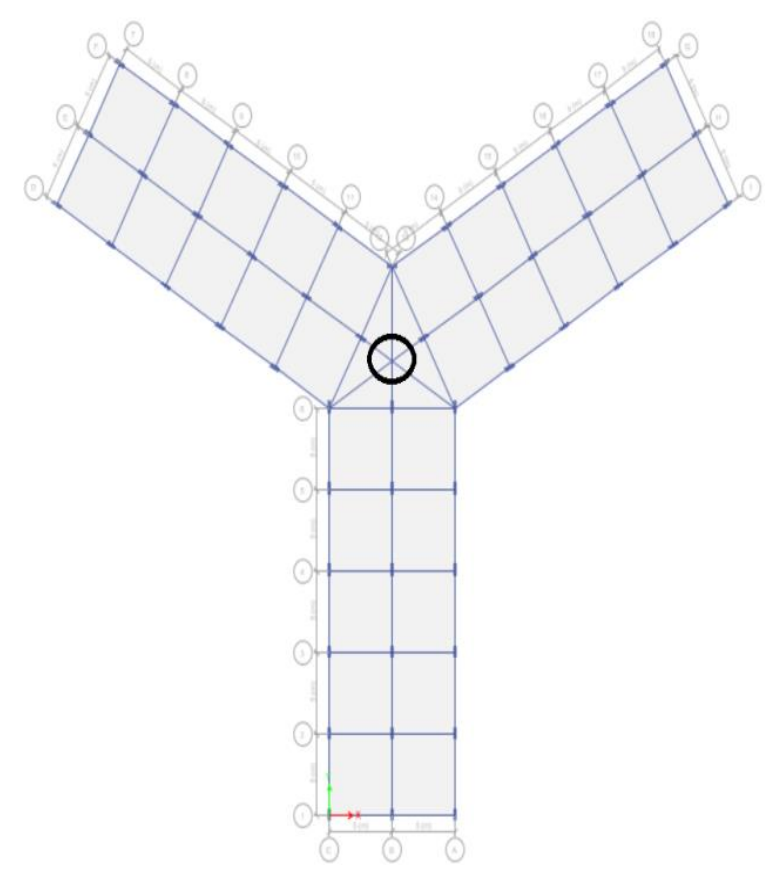

Fig. 6: Column removed location at center in plan 


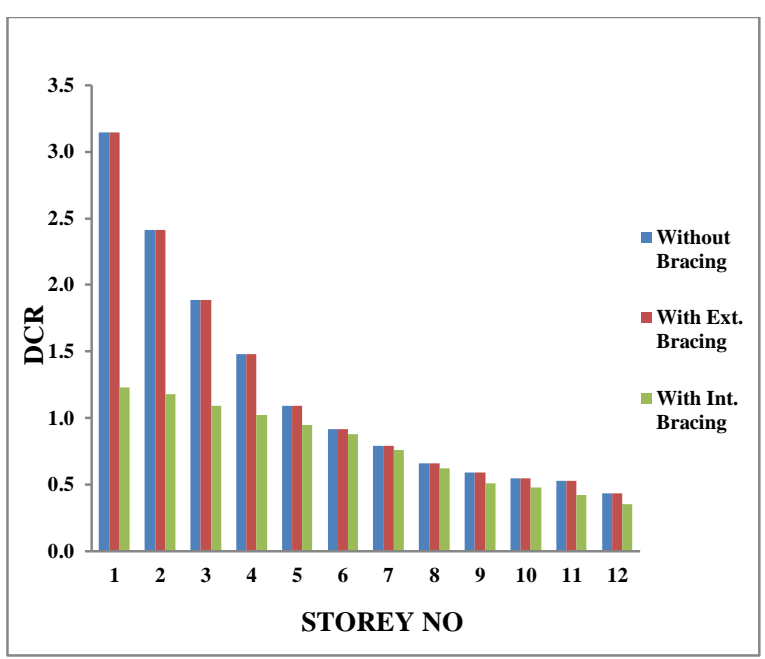

Graph 4: DCR vs Storeys for Column removed at center

In this case, the DCR value of the beam upto $3^{\text {rd }}$ storey will exceed 1.5 for both without bracing and with exterior bracing. The DCR value of all storeys is within 1.5 by providing interior bracing. Hence progressive collapse does not occur and it is less critical compared to other cases.

\section{CONCLUSIONS}

A. The members surrounding the column removal fails by exceeding the demand capacity ratio value of 1.5 for middle and interior column removal case.

B. The beams whose DCR values are less than acceptance criteria values suggested by GSA for progressive collapse guidelines are safe.

C. The DCR values for center and corner column removal case are within the limit, hence no progressive collapse occurs.

D. The middle and interior column removal case is the most critical for progressive collapse when compared to other cases.

E. By providing the bracings $(300 \times 300 \mathrm{~mm})$ in the ground storey at which column is removed, it can be made safe against progressive collapse.

F. The bracings provided adjacent to the column that is more economical for all the cases.

\section{SCOPE FOR FUTURE WORK}

A. Investigate the failure of columns located on floors other than the ground floor, for example in the middle level storey or any other storey.

B. Evaluate the DCR value and stability of building against progressive collapse at different seismic zones.
C. Compare performance of irregular and regular building at different seismic zones with or without bracings.

D. Compare performance of regular and irregular building with provision of different materials of bracings like steel, concrete etc...

E. Consider a typical building including both horizontal and vertical irregularities in the building plan.

\section{REFERENCES}

[1]. Ram Shankar Singh, Yusuf Jamal and A. Meraj Khan, "Progressive Collapse Analysis of Reinforced Concrete Symmetrical And Unsymmetrical Framed Structures By ETABS," International Journal of Innovative Research in Advanced Engineering, Vol.2, pp.78-83, 2015.

[2]. B. M. Gagan and G. Shivaraj Nayak, "Progressive Collapse Analysis of Irregular Reinforced Concrete Framed Structure," International Journal for Research in Applied Science \& Engineering Technology, Vol.7, pp.2175-2180, 2019.

[3]. Alireza Kazem, Hossein Kazemand Benyamin Monavari, "Effect of Progressive Collapse in Reinforced Concrete Structures with Irregularity in Height," Journals of World Conference on Earthquake Engineering, Vol.3, pp.1-9, 2012.

[4]. John Abruzzo, Alain Matta and Gary Panariello, "Study of Mitigation Strategies for Progressive Collapse of a Reinforced Concrete Commercial Building," Journals of Performance of Constructed Facilities @ ASCE, Vol.4, pp.384390, 2006.

[5]. Junling Chen, Wenbing Peng and Minjuan He, "Strengthening of Horizontal Bracing on Progressive Collapse Resistance of multi-storey Steel Moment Frames," Journals of Performance of Constructed Facilities @ ASCE, Vol.26 (5), pp.720-724, 2012.

[6]. Kai Qian and Bing Li, "Experimental and Analytical Assessment on RC Interior BeamColumn Sub-assemblages for Progressive Collapse," Journals of Performance of Constructed Facilities@ ASCE, Vol.26, pp.576-589, 2012.

[7]. Shalva Marjanishvili and Elizabeth Agnew, "Comparison of Various Procedure for Progressive Collapse Analysis," Journals of Performance of Constructed Facilities @ ASCE, Vol.20, pp.365374, 2006.

[8]. Vikas Tiwari and Sambhav Gangwal, "Progressive Collapse Analysis for Asymmetrical G+11 Story Tall Building using STAAD PRO," International Journal of Engineering Research \& Technology, Vol.8, pp.104-113, 2019.

[9]. J. L. Liu, "Preventing Progressive Collapse through Strengthening Beam-to-Column Connection, Part-1: Theoretical Analysis," Journals 
of Constructional Steel Research, Vol.8, pp.229237, 2009.

[10]. General Services Administration (GSA2003) Progressive collapse analysis and design guidelines for new federal office buildings and major modernization projects, GSA.

[11]. Seismic Rehabilitation of Existing Buildings, American Society of Civil Engineers (ASCE-41)

[12]. Anu Thampy, Hanna Paulose, "Assessment of Progressive Collapse Potential in Regular and Irregular RC Structures Using Linear Static Analysis", International Journal of Advance Engineering and Research Development Vol.4, Issue 6, June 2017.

[13]. C. Raghavendra, A. R. Pradeep, "Progressive Collapse Analysis of Reinforced Concrete Framed Structure", International Journal of Civil and Structural Engineering Research, ISSN 2348-7607, Vol. 2, Issue 1, 2014.

[14]. K. G. Rakshith, Radhakrishna, "Progressive collapse analysis of Reinforced Concrete framed structure," International Journal of Research in Engineering and Technology, pp.36-40, 2013.

[15]. B. R. Harinadha and P. K. Ramancharla, "Progressive Collapse Analysis of RC Buildings subjected to Seismic Loads", The Indian Concrete Journal, vol. 89, pp. 1-13, 2015. 